\title{
Antiplatelet and fibrinogenolytic activities of a purified mucus protein from Eudrilus eugeniae (African night crawler)
}

\author{
Kittidet Prem-U-domkit ${ }^{\mathrm{a}}$, Montamas Suntravat ${ }^{\mathrm{b}}$, Sara E. Lucena $^{\mathrm{b}}$, Elda E. Sánchez ${ }^{\mathrm{b}, \mathrm{d}}$, \\ Anchanee Kubera ${ }^{\mathrm{a}, \mathrm{c}, *}$ \\ a Department of Genetics, Faculty of Science, Kasetsart University, Bangkok 10900 Thailand \\ b National Natural Toxins Research Center (NNTRC), Texas A\&M University-Kingsville, Kingsville, \\ TX 78363 USA \\ c Center for Advanced Studies in Tropical Natural Resources, Kasetsart University, \\ Bangkok 10900 Thailand \\ d Department of Chemistry, Texas A\&M University-Kingsville, Kingsville, TX 78363 USA
}

*Corresponding author, e-mail: fsciacs@ku.ac.th

Received 20 Aug 2018

Accepted 29 Jun 2019

\begin{abstract}
Proteins from the earthworm mucus have been revealed for their various biological activities. In this study, a 38-kDa protein, earthworm antiplatelet agent (EAPA) was purified from the earthworm Eudrilus eugeniae (African night crawler) mucus and examined for its antiplatelet and fibrinogenolytic activities. EAPA was found to possess fibrinogenolytic activity on $\alpha$ - and $\beta$-chains of fibrinogen. It inhibited ADP-, collagen-, and ristocetin-induced platelet aggregation. This protein also had antiplatelet function on clot retraction, which was evaluated by a Sonoclot Analyser. $\mathrm{N}$-terminal amino acid sequences of EAPA shared $65 \%$ identity with lysenin, an earthworm haemolytic protein. EAPA may have potential in the development of therapeutic tools in the treatment of thrombotic diseases.
\end{abstract}

KEYWORDS: earthworm, coelomic fluid, platelet aggregation, fibrinogen

\section{INTRODUCTION}

Earthworms are annelids, and approximately 3000 species have been discovered. Lumbricus rubellus $\mathrm{H}$. (Lumbricidae) has been widely used in traditional Chinese medicine. Earthworms have been used to treat chronic bronchitis, bronchial asthma $^{1}$, digestive tract ulcers, peptic ulcers ${ }^{2}$, epidemic parotitis and herpes zoster ${ }^{3}$. Many earthworms secrete mucus, coelomic fluid, through their dorsal pores for locomotion through the soil. The components of mucus secreted by glandular cells are neutral mucopolysaccharides, proteins and lipids. These components function as a lubricant during locomotion ${ }^{4}$, ion barriers, contain mating pheromones and are involved in heavy metal absorption ${ }^{5}$. The mucus contains several bioactive molecules that are involved in innate immunity $^{6}$, and exhibit various biological activities including proteolysis, fibrinolysis, antithrombosis ${ }^{7}$, anticoagulation $^{8}$, haemolysis, antibacterial ${ }^{9}$, and anticancer activities ${ }^{10}$.

Some studies suggest that earthworm powder has thrombolytic activity. Protein from the body wall of $L$. rubellus has been purified, and six fibrinolytic isoenzymes were identified. These isoenzymes are called lumbrokinases and their molecular weights range between 23.5 and $34.2 \mathrm{kDa}^{11}$. Lumbrokinases are characterized as fibrinolytic serine protease found in L. rubellus ${ }^{11,12}$ and Eisenia fetida S. (Lumbricidae) ${ }^{13}$. These lumbrokinases were partially fractionated into three fractions (F-I, F-II, and F-III). F-I showed chymotrypsin-like activity. F-III had trypsin-like activity, and F-II had no trypsin, elastase or chymotrypsin-like activities ${ }^{12}$.

These proteolytic lumbrokinases display fibrinolytic activity, reduce platelet aggregation, increase blood viscosity, and thrombus degradation ${ }^{12,14}$. Lumbrokinases also have potential as oral thrombolytic agents ${ }^{7}$.

Platelets are generated from the cytoplasmic fragmentation of megakaryocytes in the bone marrow ${ }^{15}$ including haemostatic and thrombotic mediators ${ }^{16}$. The platelet membrane contains glycoproteins that interact with ligands and activate the platelet ${ }^{17}$. Fibrinogen is a molecule that can 
activate platelets via binding to the GPIIbIIIa integrin glycoprotein platelet receptor ${ }^{18}$. Fibrinogen molecules contain two outer D domains and a central E domain. These molecules consist of two sets of three different polypeptide chains including $\alpha$, $\beta$ and $\gamma$ chains ${ }^{19}$. GPIIbIIIa recognizes RGD (ArgGly-Asp) sequences on the fibrinogen $\alpha$-chain and promotes cell adhesion and signalling ${ }^{20}$. GPIIbIIIa competitively binds RGD sites on the $\alpha$-chain and $400-411$ sequence on the $\gamma$-chain of fibrinogen ${ }^{21}$. In this study, the antiplatelet and fibrinogenolytic activities of a protein named earthworm antiplatelet agent (EAPA) were investigated. This is the first report demonstrating that EAPA inhibits collagen, ristocetin, and ADP-induced platelet aggregation and platelet function during clot retraction. Furthermore, EAPA has fibrinogenolytic activity on fibrinogen $\alpha$ and $\beta$-chains.

\section{MATERIALS AND METHODS}

\section{Mucus protein extraction}

Earthworms were provided by Prof. Somchai Chantsavang, Department of Animal Science, Faculty of Agriculture, Kasetsart University, Thailand. This study was approved in ethical treatment of earthworms by the institutional committee under the ID ACKU59-SCI-017. The worms were extracted from their bedding, washed thoroughly with running water until dirt, soil and humus were removed. Finally, they were washed with phosphate buffer saline (PBS), pH 7.5 (Corning, VA, USA) at a ratio of 1:1 (gram of body weight/ml PBS). The earthworms were stimulated for mucus collection with an electrical impulse at $10 \mathrm{~mA}$ for 2 min using a PowerPacTM Basic power supply (Bio-Rad, MO, USA). The extracted mucus was mixed with a final concentration of $0.4 \mathrm{mM}$ phenylmethylsulphonyl fluoride (PMSF) (Sigma-Aldrich, MO, USA) and centrifuged at $1318 \mathrm{~g}$ for $15 \mathrm{~min}$. Proteins in the supernatant were precipitated with $85 \%$ saturated ammonium sulphate at $4^{\circ} \mathrm{C}$ overnight with stirring and then centrifuged at $15344 \mathrm{~g}$, at $4^{\circ} \mathrm{C}$ for $30 \mathrm{~min}$. The protein was dissolved in Milli-Q water and then dialysed against Milli-Q water using a 500 Da molecular weight cut-off dialysis membrane (Spectra/Por, TX, USA) at $4{ }^{\circ} \mathrm{C}$, lyophilized, and store at $-20^{\circ} \mathrm{C}$.

\section{Protein purification}

The lyophilized crude mucus protein was dissolved in $20 \mathrm{mM}$ Tris-HCl, pH 7.5 (equilibration buffer). Clear soluble protein $(200 \mu \mathrm{l})$, at a concentration of $40 \mathrm{mg} / \mathrm{ml}$ was applied into a Waters Protein-
PakTM DEAE 5PW $(75 \times 7.5 \mathrm{~mm})$ HPLC column. Fractions were separated using $20 \mathrm{mM}$ Tris-HCl, $\mathrm{pH} 7.5$, with $1 \mathrm{M} \mathrm{NaCl}$ gradient over $60 \mathrm{~min}$, with a flow rate at $1.0 \mathrm{ml} / \mathrm{min}$ as follows: isocratically with equilibration buffer for $5 \mathrm{~min}$, followed by linear gradients of $0-0.7 \mathrm{M} \mathrm{NaCl}$ in equilibration buffer for $30 \mathrm{~min}, 0.7 \mathrm{M} \mathrm{NaCl}$ for $5 \mathrm{~min}, 0.7-1 \mathrm{M} \mathrm{NaCl}$ for $5 \mathrm{~min}, 1 \mathrm{M} \mathrm{NaCl}$ for $5 \mathrm{~min}$, and then gradually reduced to $0 \mathrm{M} \mathrm{NaCl}$ for $5 \mathrm{~min}$. Waters 2489 Dual $\lambda$ absorbance detector (Milford, MI, USA) was used to monitor the amount of protein at $280 \mathrm{~nm}$ absorbance. Each fraction was screened for the inhibition of platelet function on clot retraction using a Sonoclot analyser. The molecular weight and protein patterns of each fraction were determined by SDS-PAGE with a NuPAGE $4-12 \%$ Bis-Tris gel. Fraction P3 showed potent antiplatelet function on clot retraction and was further purified using the same column as described above.

The pooled fraction $3(200 \mu \mathrm{l})$, at a concentration of $13.2 \mathrm{mg} / \mathrm{ml}$ was applied to the same column previously equilibrated with equilibration buffer. Separation was achieved with a linear gradient of $0-0.5 \mathrm{M} \mathrm{NaCl}$ in equilibration buffer for $45 \mathrm{~min}, 0.5-1 \mathrm{M} \mathrm{NaCl}$ for $5 \mathrm{~min}$, then isocratically with $1 \mathrm{M} \mathrm{NaCl}$ in equilibration buffer for $5 \mathrm{~min}$ and gradually reduced to $0 \mathrm{M} \mathrm{NaCl}$ for 5 min using a flow rate of $1 \mathrm{ml} / \mathrm{min}$. Waters 2489 Dual $\lambda$ absorbance detector was used to monitor absorbance at $280 \mathrm{~nm}$. Fractions with antiplatelet function on clot retraction were dialysed in PBS and concentrated using a $3 \mathrm{kDa}$ Amicon Ultra-15 centrifugal filter (Millipore, Carrigtwohill, Ireland). Protein concentrations were estimated from the absorbance at $280 \mathrm{~nm}$ using a DU 7400 spectrophotometer (Beckman Coulter, CA, USA). Purified EAPA was investigated for its biological effects on platelet aggregation and fibrinogenolytic activities.

\section{$\mathrm{N}$-terminal sequencing}

Purified EAPA ( $4 \mu \mathrm{g})$ was transferred from an SDSPAGE gel to a PVDF membrane (Milipore Corporation, MA, USA) using a Semi-Dry Transblot Cell (BIO-RAD) at $125 \mathrm{~mA}$ for $90 \mathrm{~min}$. The membrane was stained with Coomassie blue R-250 for $5 \mathrm{~min}$ and destained with $50 \%$ methanol for $5 \mathrm{~min}$. The target band was excised from the membrane and subjected to $\mathrm{N}$-terminal sequencing (17 residues) using a PPSQ-33B protein sequencer (SHIMADZU, Kyoto, Japan) following the manufacturer's instructions. Amino acid sequence similarity searches were performed against a non-redundant protein sequence databank, limiting the query to earth- 
worms (taxid:6391) using a PSI-BLAST search program from the National Center for Biotechnology Information ${ }^{22}$. Available at www.ncbi.nlm.nih.gov.

\section{Sonoclot analysis}

Coagulation and platelet function during clot retraction was measured using citrated human whole blood on a Sonoclot Coagulation and Platelet Function Analyser (SIENCO, Inc., CO, USA) according to the method of Suntravat et $\mathrm{al}^{23}$. The Sonoclot Analyser measures the activated clot time (ACT), clot rate (CR), and platelet function (PF) in clot retraction by measuring the viscosity changes of whole blood or plasma sample. The clot rate is defined as the change in clot signal over time. The platelet function is obtained from the timing and quality of the clot retraction. Briefly, a cuvette containing glass beads (gbACT + KIT) was placed into the cuvette holder, which maintained the temperature at $37^{\circ} \mathrm{C}$. A pre-warmed $10 \mu \mathrm{l}$ sample $\left(37^{\circ} \mathrm{C}\right)$ of a $0.3 \mathrm{M} \mathrm{CaCl}_{2}$ was added to one side of the cuvette. A $10 \mu \mathrm{l}$ sample of each mucus fraction at a concentration of $1 \mathrm{mg} / \mathrm{ml}$ or a $10 \mu \mathrm{l}$ of purified EAPA at various concentrations was added to the other side of the cuvette. Subsequently, $330 \mu 1$ of citrated blood was added to the cuvette. The data were downloaded from Signature Viewer program v. 4.1, software provided by SIENCO, Inc. and analysed in EXCEL 2010. The control was citrated blood that was activated with glass beads and $0.3 \mathrm{M} \mathrm{CaCl}_{2}$. All experiments were done in 3 replicates.

\section{Platelet aggregation assay}

The inhibition of collagen-, ristocetin-, and ADPinduced platelet aggregation by either crude mucus protein or purified E. eugeniae EAPA was determined by measuring the impedance of whole human blood in a ChronoLog Whole Blood Aggregometer (ChronoLog, PA, USA) as previously described ${ }^{24}$. Four hundred and fifty microlitres of $10 \%$ citrated whole human blood was added in the platelet aggregometer cuvette with a magnetic stirrer and incubated at $37^{\circ} \mathrm{C}$ at least $5 \mathrm{~min}$ prior to use with equal amounts of $0.15 \mathrm{M} \mathrm{NaCl}$. Purified EAPA at various concentrations $(10 \mu \mathrm{l})$ was incubated with blood samples in a ChronoLog Whole Blood Aggregometer (Chrono-log, PA, USA) and stirred in the test cuvette at $1200 \mathrm{rpm}$ at $37^{\circ} \mathrm{C}$ for $2 \mathrm{~min}$. Platelet aggregation was initiated by adding ristocetin $(1 \mathrm{mg} / \mathrm{ml})$, collagen $(2 \mu \mathrm{g} / \mathrm{ml})$, and ADP $(10 \mu \mathrm{M})$. All three agonists were purchased from ChronoLog. The percentage inhibition of platelet aggregation was calculated using the following equation: $(C-E / C) \times$
100 , where $C$ is platelet aggregation $(\Omega)$ for the control, and $E$ is platelet aggregation $(\Omega)$ for the experimental fraction. The extent of platelet aggregation inhibition was assessed by comparison to the maximal aggregation induced by the control dose of agonists (collagen, ristocetin, and ADP). The half maximum of inhibition concentration $\left(\mathrm{IC}_{50}\right.$ ) values were determined from dose-response curves generated using various concentrations of purified EAPA using GraphPad Prism6 (GraphPad Software Inc., CA, USA). All experiments were done in 3 replicates.

\section{Fibrinogenolytic assay}

The activity of purified EAPA was tested on fibrinogen. Briefly, $20 \mu \mathrm{l}$ of $5 \mathrm{mg} / \mathrm{ml}$ fibrinogen (Hyphen Biomed, OH, USA) was mixed with a $10 \mu \mathrm{l}$ of purified EAPA at various concentrations and incubated at $37^{\circ} \mathrm{C}$ for $24 \mathrm{~h}$. The final concentration of fibrinogen was $3.3 \mathrm{mg} / \mathrm{ml}$. The reactions were stopped by addition of sample denaturing buffer and analysed by NuPAGE 4-12\% Bis-Tris gel (Invitrogen, USA). The venom of Crotalus atrox at $0.5 \mathrm{mg} / \mathrm{ml}$ (final concentration), which has been reported to have fibrinogenolytic activity, was used as a positive control $^{25}$. All experiments were done in 3 replicates.

\section{Statistical analysis}

The results are shown as the mean \pm standard deviation (SD). Significance was determined using the Student's $t$-test. Significance level was set at $p<$ 0.05 compared to the control. The nonlinear curve fit was generated using GraphPad Prism6 (GraphPad Software Inc., CA, USA).

\section{RESULTS}

\section{Purification of EAPA}

The crude mucus protein was first fractionated on a DEAE 5PW column. From the 13 fractions, fractions P1-P4 inhibited platelet function (Fig. 1a). Fraction P3 had potent antiplatelet activity and contained at least three different proteins (Fig. 1b and Table 1), which were further purified on the same column. The proteins were isolated into two fractions (Fig. 1c). Fraction P3P2 contained a single band at approximately $38 \mathrm{kDa}$ by SDSPAGE (Fig. 1d) and was named EAPA. A protein BLAST search and CLUSTAL Omega multiple sequence alignments revealed that the first 17 amino acids of EAPA showed $65 \%$ identity with lysenin 

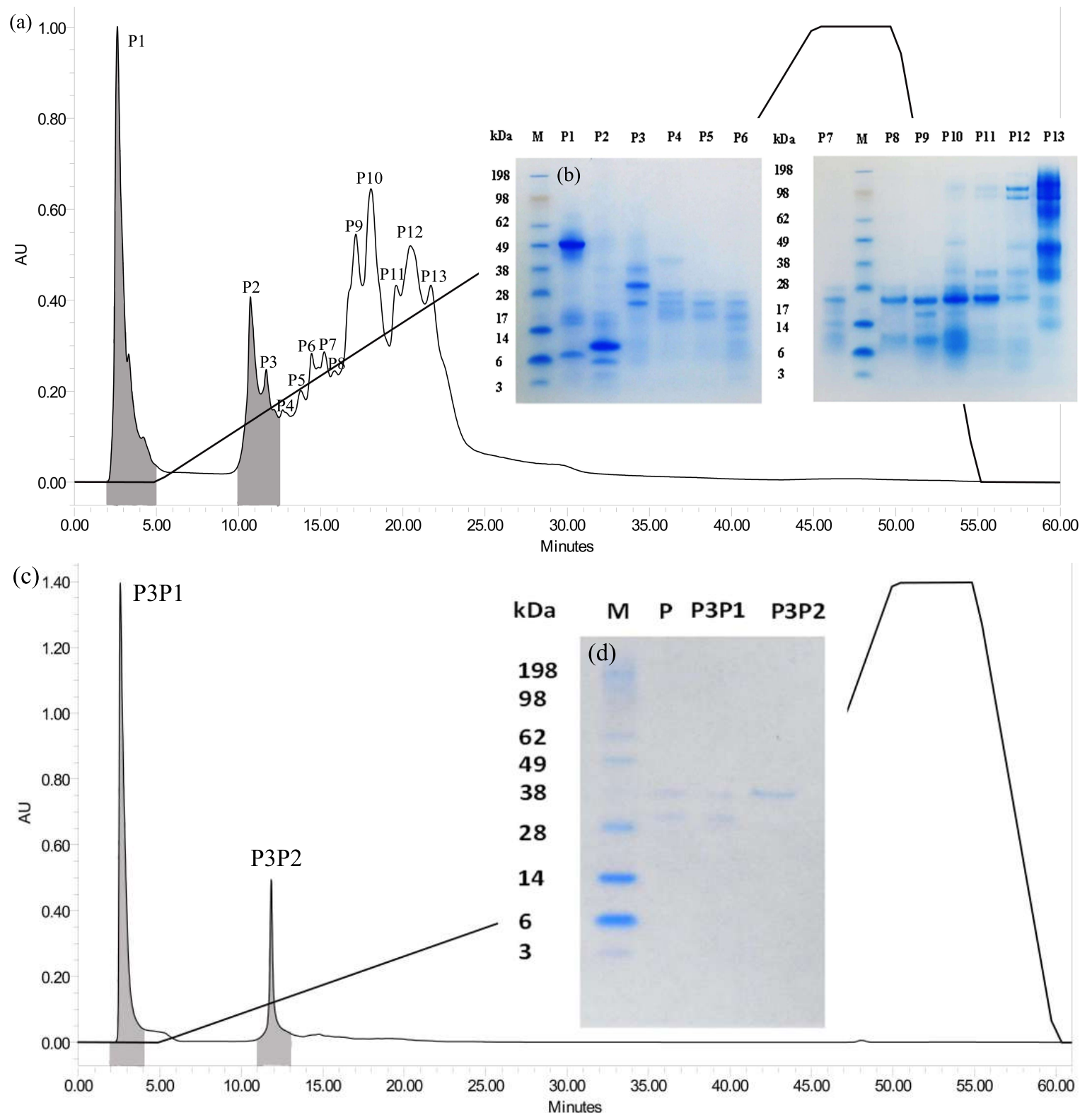

Fig. 1 (a) DEAE anion exchange chromatographic profile of mucus protein of E. eugeniae. The grey-shaded areas indicate the location of antiplatelet function on clot retraction using a Sonoclot analyser. (b) SDS-PAGE analysis of the fractions from the first step purification. Fractionated mucus proteins (P1-P13) were run on 4-12\% Bis-Tris gel under non-reducing conditions at $100 \mathrm{~V}$ for $95 \mathrm{~min}$. Gel was stained by SimplyBlue SafeStain. (c) The second purification of fraction 3 (P3) using DEAE anion exchange with different gradient of elution buffer. The grey-shaded areas indicate the location of antiplatelet function on clot retraction using the Sonoclot analysis. (d) SDS-PAGE analysis of purified P3P2, named EAPA.

pore [5EC5_A] and lysenin-related protein 1 (LRP1) $[018424.1], 41 \%$ identity with lysenin-related protein 2 (LRP-2) [BAA21520] and was 59\% identical to lysenin-related protein 3 (LRP-3) [Q3LX99.1], bioactive proteins isolated from coelomic fluid of the earthworm, E. fetida (Fig. 2). The yield of EAPA was
$0.05 \%$ by weight of the crude mucus protein.

\section{Sonoclot analysis}

The effect of EAPA on coagulation and platelet function was determined by measuring the ACT, $\mathrm{CR}$, and PF (clot retraction) using the Sonoclot 
Table 1 The ACT, clot rate and platelet function of positive control, crude mucus protein and fractions from first purification were shown and these data were given by Sonoclot analyser and downloaded with Signature Viewer; software provided by Sienco, Inc. and analysed by EXCEL 2010 !

\begin{tabular}{|c|c|c|c|c|c|c|c|}
\hline \multirow[t]{2}{*}{ Sample } & \multirow{2}{*}{$\begin{array}{c}\text { Protein } \\
(\mu g)\end{array}$} & \multicolumn{2}{|c|}{ ACT } & \multicolumn{2}{|c|}{ Clot rate } & \multicolumn{2}{|c|}{ Platelet function } \\
\hline & & $(\min )$ & $p$-value & (U) & $p$-value & & $p$-value \\
\hline $1 \mathrm{X}$ PBS & 0 & $2.85 \pm 0.35$ & & $25.33 \pm 8.82$ & & $2.93 \pm 0.29$ & \\
\hline $\mathrm{P} 1$ & 10 & $2.24 \pm 0.32^{\mathrm{a}}$ & $1.38 \times 10^{-2}$ & $24.67 \pm 3.51$ & 1.00 & $0.73 \pm 0.15^{\mathrm{a}}$ & $1.60 \times 10^{-3}$ \\
\hline P2 & 10 & $2.15 \pm 0.15^{\mathrm{a}}$ & $3.30 \times 10^{-3}$ & $29.67 \pm 3.05$ & $8.05 \times 10^{-1}$ & $0.37 \pm 0.15^{\mathrm{a}}$ & $8.00 \times 10^{-4}$ \\
\hline P3 & 10 & $1.81 \pm 0.10^{\mathrm{a}}$ & $2.00 \times 10^{-3}$ & $29.67 \pm 2.52$ & $8.05 \times 10^{-1}$ & $0.43 \pm 0.32^{\mathrm{a}}$ & $2.60 \times 10^{-3}$ \\
\hline P4 & 10 & $2.27 \pm 0.05^{\mathrm{a}}$ & $2.13 \times 10^{-2}$ & $26.33 \pm 2.52$ & 1.00 & $0.77 \pm 0.15^{\mathrm{a}}$ & $1.50 \times 10^{-3}$ \\
\hline P5 & 10 & $2.19 \pm 0.62^{\mathrm{a}}$ & $6.20 \times 10^{-3}$ & $31.33 \pm 4.16$ & $4.46 \times 10^{-1}$ & $2.70 \pm 0.56$ & $3.12 \times 10^{-1}$ \\
\hline P6 & 10 & $2.30 \pm 0.24^{\mathrm{a}}$ & $3.11 \times 10^{-2}$ & $32.33 \pm 4.04$ & $2.72 \times 10^{-1}$ & $2.60 \pm 1.08$ & $9.99 \times 10^{-1}$ \\
\hline P7 & 10 & $2.48 \pm 0.05$ & $2.71 \times 10^{-1}$ & $32.33 \pm 1.53$ & $2.72 \times 10^{-1}$ & $2.30 \pm 0.40$ & $7.67 \times 10^{-1}$ \\
\hline P8 & 10 & $2.54 \pm 0.16$ & $6.55 \times 10^{-1}$ & $30.50 \pm 0.71$ & $7.76 \times 10^{-1}$ & $2.20 \pm 0.85$ & $7.64 \times 10^{-1}$ \\
\hline P9 & 10 & $2.08 \pm 0.15^{\mathrm{a}}$ & $1.10 \times 10^{-3}$ & $38.00 \pm 0.70^{\mathrm{b}}$ & $5.10 \times 10^{-3}$ & $1.33 \pm 0.23^{\mathrm{a}}$ & $1.10 \times 10^{-3}$ \\
\hline P10 & 10 & $1.67 \pm 0.05^{\mathrm{a}}$ & $1.40 \times 10^{-3}$ & $45.67 \pm 2.08^{b}$ & $5.00 \times 10^{-4}$ & $1.27 \pm 0.31^{\mathrm{a}}$ & $6.00 \times 10^{-4}$ \\
\hline P11 & 10 & $1.77 \pm 0.06^{\mathrm{a}}$ & $2.60 \times 10^{-3}$ & $39.00 \pm 2.65^{b}$ & $2.20 \times 10^{-3}$ & $1.87 \pm 0.59^{\mathrm{a}}$ & $8.81 \times 10^{-3}$ \\
\hline P12 & 10 & $1.86 \pm 0.13^{\mathrm{a}}$ & $2.50 \times 10^{-3}$ & $43.67 \pm 1.53^{b}$ & $6.00 \times 10^{-4}$ & $1.33 \pm 0.06^{\mathrm{a}}$ & $1.10 \times 10^{-3}$ \\
\hline P13 & 10 & $2.37 \pm 0.02$ & $7.60 \times 10^{-2}$ & $33.67 \pm 2.08$ & $1.25 \times 10^{-1}$ & $1.40 \pm 0.17^{\mathrm{a}}$ & $2.00 \times 10^{-3}$ \\
\hline
\end{tabular}

$\dagger$ The values are displayed as mean \pm SD with $n=3$. ${ }^{\text {a }}$ indicates the significant reduction of ACT and platelet function at $p<0.05 .{ }^{\mathrm{b}}$ indicates the significant increasing of clot rate at $p<0.05$.

Table 2 Sonoclot analysis of whole blood coagulation and platelet retraction with purified EAPA!

\begin{tabular}{lccccccc}
\hline Sample & Protein & \multicolumn{2}{c}{ ACT } & \multicolumn{2}{c}{ Clot rate } & \multicolumn{2}{c}{ Platelet function } \\
\cline { 2 - 8 } & $(\mu \mathrm{g})$ & $(\mathrm{min})$ & $p$-value & $(\mathrm{U})$ & $p$-value & $p$-value \\
\hline 1X PBS (negative control) & 0 & $3.07 \pm 0.50$ & 1 & $22.7 \pm 1.5$ & 1 & $3.37 \pm 0.55$ & 1 \\
EAPA $(0.01 \mathrm{mg} / \mathrm{ml})$ & 0.1 & $2.32 \pm 0.47$ & $5.38 \times 10^{-2}$ & $27.3 \pm 1.5^{\mathrm{b}}$ & $2.01 \times 10^{-2}$ & $2.37 \pm 0.81$ & $1.53 \times 10^{-1}$ \\
EAPA $(0.05 \mathrm{mg} / \mathrm{ml})$ & 0.5 & $1.79 \pm 0.01^{\mathrm{a}}$ & $3.51 \times 10^{-2}$ & $32.0 \pm 5.2^{\mathrm{b}}$ & $4.05 \times 10^{-2}$ & $0.03 \pm 0.06^{\mathrm{a}}$ & $8.42 \times 10^{-3}$ \\
EAPA $(0.4 \mathrm{mg} / \mathrm{ml})$ & 4 & $1.80 \pm 0.05^{\mathrm{a}}$ & $3.59 \times 10^{-2}$ & $29.1 \pm 0.1^{\mathrm{b}}$ & $1.12 \times 10^{-2}$ & $0.00 \pm 0.01^{\mathrm{a}}$ & $8.81 \times 10^{-3}$ \\
\hline
\end{tabular}

$\dagger$ The values are displayed as mean \pm SD with $n=3$. ${ }^{\text {a }}$ indicates the significant reduction of ACT and platelet function at $p<0.05$. ${ }^{\mathrm{b}}$ indicates the significant increasing of clot rate at $p<0.05$.

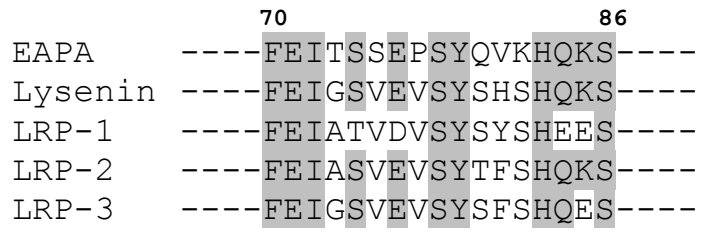

Fig. 2 Multiple alignment of the N-terminal amino acid sequences of purified EAPA with the residue at 70-86 of lysenin (5EC5_A), LRP-1 (BAA21519), LRP-2 (BAA21520), and LRP-3 (Q3LX99.1). The alignment was generated with the Clustal Omega multiple sequence alignment program with manual adjustment and displayed with shaded boxes.

analyser. Sonoclot signatures from representative samples are shown in Fig. 3. Purified EAPA showed pro-coagulant activity and strong dose-dependent antiplatelet function on clot retraction (Table 2).

\section{Inhibition of platelet aggregation}

Purified EAPA inhibited collagen-, ristocetin-, and ADP-induced platelet aggregation in a dosedependent manner, with $\mathrm{IC}_{50}$ of $0.85,0.93$, and $1.03 \mathrm{mg} / \mathrm{ml}$, respectively (Fig. 4). The strongest inhibition was observed with EAPA in the presence of collagen.

\section{Fibrinogenolytic assay}

As $C$. atrox snake venom is known to have $\alpha$ and $\beta$ fibrinogenase activity, therefore, the effect of crude venom on fibrinogen was used as a positive control (P). When incubated with fibrinogen, purified EAPA preferentially cleaved the $\alpha$ chain of fibrinogen and cleaved the $\beta$ chain at a higher concentration but did not cleave the $\gamma$ chain (Fig. 5). EAPA showed significant $\alpha$ - and $\beta$-chain digestion at $0.02-0.32 \mathrm{mg} / \mathrm{ml}$ concentrations. 




Fig. 3 Sonoclot signatures of purified EAPA using human whole blood. Three different concentrations of purified EAPA at $0.01,0.05$, and $0.4 \mathrm{mg} / \mathrm{ml}$ (starting concentrations) were individually added with whole blood using glass bead activated cuvettes (gbACT + KIT) on a Sonoclot analyser system. The data was obtained by the program Signature Viewer 3.1 and analysed by EXCEL 2010. ACT=activated clot time.

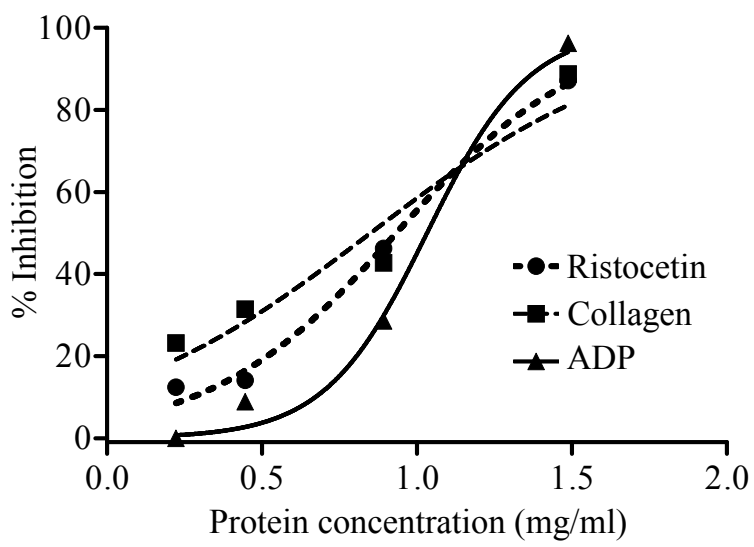

Fig. 4 EAPA inhibited platelet aggregation in the presence of different three agonists. The $\mathrm{IC}_{50}$ values for inhibiting platelet aggregation by collagen, ristocetin, and $\mathrm{ADP}$ are indicated by $\mathrm{IC}_{50} \pm \mathrm{SD}$ as these following $0.85 \pm 0.10 \mu \mathrm{g} / \mathrm{ml}, 0.93 \pm 0.03 \mu \mathrm{g} / \mathrm{ml}$, and $1.03 \pm 0.04 \mu \mathrm{g} / \mathrm{ml}$, respectively. The $R^{2}$ of nonlinear regression of collagen, ristocetin, and ADP are indicated by $0.93,0.99$, and 0.99 , respectively. The vertical bars represent the $\mathrm{SD}, n=3$.

\section{DISCUSSION}

Thrombosis is a major factor that contributes to cardiovascular diseases. Thromboembolic vascular disease can be treated with fibrinolytic enzymes such as

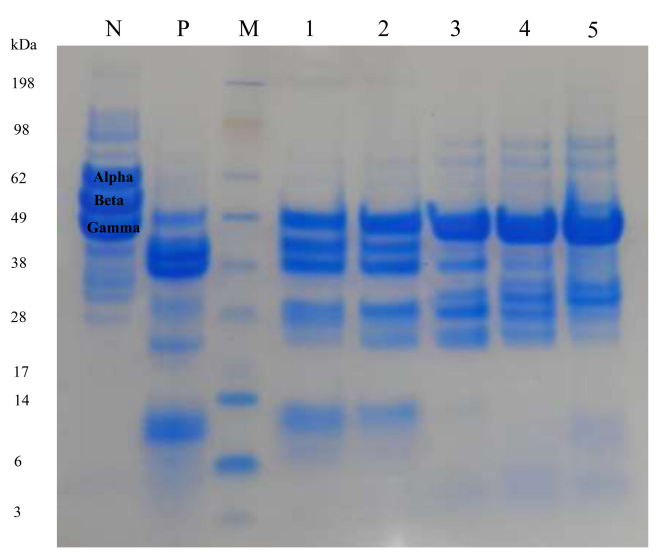

Fig. 5 Fibrinogenolytic activity of purified EAPA. Migration pattern of the fragments formed at $24 \mathrm{~h}$-incubation were analysed on 4-12\% SDS-PAGE under reduced condition and Coomassie blue stained. $\alpha, \beta$, and $\gamma$ chains fibrinogen are indicated in the negative control $(\mathrm{N})$; absence of a particular chain indicates hydrolysis. C. atrox venom was used as a positive control (P). M: See Blue Plus2 Markers (InvitrogenT); lanes 1-5: human fibrinogen incubated with EAPA at the final concentrations of $0.32,0.16,0.08,0.04$, and $0.02 \mathrm{mg} / \mathrm{ml}$, respectively.

urokinase, tissue-type plasminogen activator (t-PA), streptokinase, and staphylokinase. These enzymes have been clinically studied as thrombolytic agents and have demonstrated thrombolytic activities ${ }^{26}$. However, these enzymes produce plasmin in the circulatory system in addition to intravascular anticoagulation side effects ${ }^{27,28}$. Hence antithrombotic agents are needed to improve and reduce adverse effects without impairing efficacy.

Fibrinolytic serine protease enzymes have been purified and characterized from several earthworm species including $L$. rubellus, Indian earthworm Pheretima posthumous J. (Diporochaeta), and E. fetida ${ }^{29,30}$. These earthworm fibrinolytic enzymes have shown promising antithrombotic and fibrinolytic activities. However, to date, no platelet aggregation inhibitor has been identified in E. eugeniae. Hence the focus of this study was to identify and characterize an E. eugeniae antiplatelet agent.

The N-terminal amino acid sequence comparison of EAPA to lysenin and lysenin-related proteins (LRP-1 and LRP-2 also known as fetidin, and LRP3) revealed the presence of conserved amino acid residues. However, it should be noted that this homology is based on the comparison of amino 
acids at the N-terminus and does not take into account the remaining EAPA sequence. Fetidin/lysenin family proteins are found in the coelomic fluid of E. fetida. Lysenin has high sequence similarity to fetidin (89\% identity), LRP-1 (76\% identity), and LRP-3 (81\% identity) ${ }^{30}$. Although these proteins have sequence similarities, they could have different biological functions. The molecular weights of these proteins are within the range of $35-41 \mathrm{kDa}$, which is consistent with the molecular weight of EAPA according to our SDS-PAGE protein band (38 $\mathrm{kDa}$ ). Lysenin belongs to a pore-forming toxin that binds specifically to sphingomyelin leading to pore formation and consequent cell lysi ${ }^{31}$. Fetidin also exhibits haemolysis, agglutination, antibacterial, and coagulation properties ${ }^{32}$. The three-dimensional structure of monomeric lysenin shows that this protein is composed of two domains. The first domain is an elongated pore-forming module at the N-terminus with a sphingomyelin (SM) binding site (Lys21, Tyr24, Tyr26, Gln117, and Glu128). The second domain is the C-terminal beta-trefoil domain, which binds to phosphocholine. The SM is likely involved in platelet activation by lysenin ${ }^{33}$. Furthermore, lysenin irreversibly induces platelet aggregation ${ }^{32}$.

Here, we show that EAPA has antiplatelet activity with a shortened ACT compared to the control (Table 1 and Fig. 3). However, it should be noted that the ACT value for EAPA at concentrations of $0.01-0.4 \mathrm{mg} / \mathrm{ml}$ (Table 2) is considered within a normal range (1.6-2.6 min). The ACT values are quantified from the onset time of the clot formation, CR is calculated from the maximum slope of the Sonoclot signature curve during initial fibrin polymerization and $\mathrm{PF}$ values are measured from the starting time $(0 \mathrm{~min})$ to the time when a peak reach to the highest point that referred to timing and quality of clot retraction. The clot signal curves of 0.4 and $0.05 \mathrm{mg} / \mathrm{ml}$ EAPA showed early onset of low clot formation levels with higher $\mathrm{CR}$ when compared to $0.01 \mathrm{mg} / \mathrm{ml}$ EAPA and control and for the first 2$3 \mathrm{~min}$, the clot formations were inhibited. Thus the clot signal could not reach a peak, which indicates that there is no clot retraction at 0.4 and $0.05 \mathrm{mg} / \mathrm{ml}$ EAPA. Platelets play a key role in haemostasis and thrombosis. The ability of $\alpha \operatorname{IIb} \beta 3$ integrins on the surface of platelets to bind to fibrinogen plays an important role in platelet adhesion, aggregation, and haemostasis. GPIIbIIIa on platelet membrane is a calcium-dependent heterodimeric glycoprotein receptor ${ }^{34}$. This receptor recognizes the Arg-GlyAsp (RGD) sequence on the $\alpha$-chain of fibrinogen and mediates fibrinogen binding ${ }^{35}$. The two RGD sequences are found in the $\alpha$-chain of fibrinogen while the C-terminus of the fibrinogen $\gamma$-chain in fibrinogen is essential for platelet adhesion ${ }^{36}$. Collagen mainly involves aggregation mediated by the interaction between the platelet membrane glycoprotein VI (GPVI) and integrin $\alpha 2 \beta 1$, while ristocetin induces the binding of VWF to platelet glycoprotein Ib $\alpha$ (GPIb $\alpha)$. Hence the platelet aggregation inhibitory activity was examined using ADP (P2Y1 and P2Y12 ADP receptors agonist), ristocetin (von Willebrand factor, VWF agonist), and collagen (integrin $\alpha 2 \beta 1$ and GPVI agonist) ${ }^{37}$. We found that EAPA had the most potent inhibitory effect on collagen-induced platelet aggregation. It is possible that EAPA acts on collagen receptors (integrin $\alpha 2 \beta 1$, and/or GPVI), or on integrin $\alpha \operatorname{IIb} \beta 3$, GPIb $\alpha$, either alone or in a complex with VWF. However, other EAPA-integrin interactions should be investigated. Fibrinogen is a plasma protein that interacts with integrin $\alpha \operatorname{IIb} \beta 3$ to mediate a variety of platelet responses including adhesion, aggregation, and clot retraction ${ }^{38}$. Proteolysis of fibrinogen segments can result in its inability to interact with platelet integrin $\alpha \operatorname{IIb} \beta 3$ leading to a reduction in the platelet response. To confirm the EAPA antiplatelet activity we employed an in vitro fibrinogen cleavage assay. We observed that EAPA cleaves fibrinogen $\alpha$ - and $\beta$-chains (Fig. 5). Thus the in vitro inhibition of platelet aggregation by EAPA can be explained, at least partly, by the digestion of plasma fibrinogen, which is required for bridging platelets via $\alpha \operatorname{IIb} \beta 3$ receptors.

To develop EAPA as a therapeutic tool, this protein should be tested in animal implication, protein stability and protein production.

Acknowledgements: This work was supported by funds from Development and Promotion of Science and Technology Talents (DPST) Project, Kasetsart University Research and Development Institute of Kasetsart University, Thailand, and NIH-ORIP/BMRG, Viper Resource Grant \#s 3P40OD010960-13 (NNTRC, Texas A\&M UniversityKingsville, Dr E.E. Sánchez). The National Natural Toxin Research Center at Texas A\&M University Kingsville, TX, USA provided facilities for this study. The authors declare that they have no competing interests.

\section{REFERENCES}

1. Liang YL (1984) Application of earthworm in treating asthma. $J$ Tradit Chin Med 4, 15-16.

2. Mu DJ (1988) Report of 40 cases digestive ulcer treated with earthworm powder. $J$ Tradit Chin Med 29, 21-23. 
3. Liu XF (1983) Twenty-six cases of Allium tuberous root and earthworm on herpes zoster. Henan $J$ Tradit Chin Med 6, 14-16.

4. Richards KS (1973) The histochemistry of the large granular, orthochromatic, mucous cells of some lumbricides. Ann Histochem 18, 289-300.

5. Richards KS (1974) The histochemistry of the metachromaticmucous cells of some lumbricides. Ann Histochem 19, 187-197.

6. Cooper EL, Roch P (2003) Earthworm immunity: a model of immune competence. Pedobiologia 47, 676-688.

7. Tram T, Phan B, Ta T, Nguyen DTX, Broek LAVD, Duong GTH (2011) Purification and characterization of novel fibrinolytic proteases as potential antithrombotic agents from earthworm Perionyx excavatus. AMB Express 1, 26.

8. Terezija H, Maja P, Tamara B, Mira GD, Ljerka T (1998) Fibrinolytic and anticoagulant activities from the earthworm Eisenia foetida. Comp Biochem Phys B 119, 825-832.

9. Beschin A, Bilej M, Hanssens F, Raymakers J, Van DE, Revets H, Brys L, Gomez J, Baetselier PD, Timmermans M (1998) Identification and cloning of $\alpha$ glucan-and lipopolysaccharide-binding protein from Eisenia fetida earthworm involved in the activation of prophenoloxidase cascade. J Biol Chem 273, 24948-24954.

10. Yanqin L, Yan S, Zhenjun S, Shijie L, Chong W, Yan L, Yuhong G (2007) Coelomic fluid of the earthworm Eisenia fetida induces apoptosis of HeLa cells in vitro. Eur J Soil Biol 43, S143-S148.

11. Mihara H, Sumi H, Yoneta T, Mizumoto H, Ikeda R, Seiki M, Maruyama M (1991) A novel fibrinolytic enzyme extracted from the earthworm, Lumbricus rubellus. Jpn J Physiol 41, 461-472.

12. Nakajima N, Mihara H, Sumi H (1993) Characterization of potent fibrinolytic enzymes in earthworm Lumbricus rubellus. Biosci Biotechnol Biochem 57, 1726-1730.

13. Yang JS, Ru BG (1997) Purification and characterization of an SDS-activated fibrinolytic enzyme from Eisenia fetida. Comp Biochem Physiol B Biochem Mol Biol 118, 623-631.

14. Yan XM, Kim CH, Lee CK, Shin JS, Cho IH, Sohn UD (2010) Intestinal absorption of fibrinolytic and proteolytic lumbrokinase extracted from earthworm, Eisenia andrei. Korean J Physiol Pharmacol 14, 71-75.

15. Hanson SR, Slichter SJ (1985) Platelet kinetics in patients with bone marrow hypoplasia: evidence for a fixed platelet requirement. Blood 66, 1105-1109.

16. White JG, Krumwiede MD, Escolar G (1999) Glycoprotein $\mathrm{Ib}$ is homogeneously distributed on external and internal membranes of resting platelets. Am $J$ Pathol 155, 2127-2134.

17. White JG, Clawson CC (1980) The surface-connected canalicular system of blood platelets-a fenestrated membrane system. Am J Pathol 101, 353-364.

18. Hynes RO (1987) Integrins: a family of cell surface receptors. Cell 48, 549-554.

19. Huang S, Cao Z, Davie EW (1993) The role of amino-terminal disulfide bonds in the structure and assembly of human fibrinogen. Biochem Biophys Res Commun 190, 488-495.

20. Belkin AM, Tsurupa G, Zemskov E, Veklich Y, Weisel JW, Medved L (2005) Transglutaminase-mediated oligomerization of the fibrinogen $\alpha \mathrm{C}$-domains promotes integrin-dependent cell adhesion and signaling. Blood 105, 3561-3568.

21. Kloczewiak M, Timmons S, Lukas TJ, Hawiger J (1984) Platelet receptor recognition site on human fibrinogen. Synthesis and structure function relationship of peptides corresponding to the C-terminal segment of the c chain. Biochemistry 23, 1767-1774.

22. Altschul SF, Madden TL, Schäffer AA, Zhang J, Zhang Z, Miller W, Lipman DJ (1997) Gapped BLAST and PSI-BLAST: a new generation of protein database search programs. Nucleic Acids Res 25, 3389-3402.

23. Suntravat M, Jia Y, Lucena SE, Perez JC, Sánchez EE (2013) cDNA cloning of a snake venom metalloproteinase from the eastern diamondback rattlesnake (Crotalus adamanteus), and the expression of its disintegrin domain with antiplatelet effects. Toxicon 64, 43-54.

24. Suntravat M, Helmke TJ, Atphaisit C, Cuevas E, Lucena SE, Uzcátegui NL, Sánchez EE, RodriguezAcosta A (2016) Expression, purification, and analysis of three recombinant ECD disintegrins (RColombistatins) from P-Iii class snake venom metalloproteinases affecting platelet aggregation and SKMEL-28 cell adhesion. Toxicon 122, 43-49.

25. Markland FS Jr (1998) Snake venom fibrinogenolytic and fibrinolytic enzymes: an updated inventory. Registry of Exogenous Hemostatic Factors of the Scientific and Standardization Committee of the International Society on Thrombosis and Haemostasis. Thromb Haemost 79, 668-674.

26. Margres MJ, Walls $R$, Suntravat M, Lucena $S$, Sánchez EE, Rokyta DR (2016) Functional characterizations of venom phenotypes in the eastern diamondback rattlesnake (Crotalus adamanteus) and evidence for expression-driven divergence in toxic activities among populations. Toxicon 119, 28-38.

27. Lijnen HR, Collen D (1995) Fibrinolytic agents: mechanisms of activity and pharmacology. Thromb Haemost 74, 387-390.

28. Takahama T, Kanai F, Onishi K, Yamazaki Z, Furuse A, Yoshitake T (1995) Danger of urokinase as an anticoagulant with left ventricular assist devices. ASAIO J 41, M787-M790.

29. Zhao J, Pan R, He J, Lui Y, Li DF, He RQ (2007) Eisenia fetida protease-III-I functions in both fibrinolysis and fibrinogenmesis. J Biomed Biotec 2007, 1-10.

30. Verma MK, Pulicherla KK (2017) Broad substrate 
affinity and catalytic diversity of fibrinolytic enzyme from Pheretima posthumous-Purification and molecular characterization study. Int J Biol Macromol 95, 1011-1021.

31. Yilmaz N, Yamaji-Hasegawa A, Hullin-Matsuda F, Kobayashi T (2018) Molecular mechanisms of action of sphingomyelin-specific pore-forming toxin, lysenin. Semin Cell Dev Biol 73, 188-198.

32. Yamaji A, Sekizawa Y, Emoto K, Sakuraba H, Inoue K, Kobayashi H, Umeda M (1998) Lysenin, a novel sphingomyelin-specific binding protein. $J$ Biol Chem 273, 5300-5306.

33. Zachowski A (1993) Phospholipids in animal eukaryotic membranes: Transverse asymmetry and movement. Biochem J 294, 1-14.

34. Valembois P, Roch P, Lassegues M (1988) Evidence of plasma clotting system in earthworms. J Invert Pathol 51, 221-228.
35. Jennings LK, Phillips DR (1982) Purification of glycoproteins IIb and III from human platelet plasma membranes and characterization of a calcium dependent glycoprotein IIb-III complex. J Biol Chem 257, 10458-10466.

36. Farrell DH, Thiagarajan P, Chung DW, Davie EW (1992) Role of fibrinogen alpha and gamma chain sites in platelet aggregation. PNAS 89, 10729-10732.

37. Gitz E, Koopman CD, Giannas A, Koekman CA, van den Heuvel DJ, Deckmyn H, Akkerman NJ, Gerritsen HC, Urbanus RT (2013) Platelet interaction with von Willebrand factor is enhanced by shear-induced clustering of glycoprotein Ib $\alpha$. Haematologica 98, 1810-1818.

38. Lisman T, Weeterings C, de Groot PG (2005) Platelet aggregation: involvement of thrombin and fibrinogen. Front Biosci 10, 2504-2517. 